Jurnal Agro Vol. III, No. 1, Juli 2016

\title{
PEMANFAATAN ZEOLIT DAN DOLOMIT SEBAGAI PEMBENAH UNTUK MENINGKATKAN EFISIENSI PEMUPUKAN PADA LAHAN SAWAH
}

\section{UTILIZATION OF ZEOLIT AND DOLOMITE AS SOIL CONDITIONER TO INCREASE FERTILIZATION EFFICIENCY IN RICE FIELD}

\author{
Ishak Juarsah \\ Balai Penelitian Tanah, JI. Ir,H. Juanda 98 Bogor \\ Korespondensi : juarsah@yahoo.com
}

Diterima 27 November 2015 /Disetujui 23 Juli 2016

\begin{abstract}
ABSTRAK
Salah satu upaya alternatif untuk meningkatkan kualitas lahan sawah yang telah terdegradasi adalah mengaplikasikan zeolit dan dolomit yang dikombinasi dengan pengelolaan bahan organik serta sistem pemupukan berimbang yang spesifik lokasi berdasarkan uji tanah dan kebutuhan tanaman. Pemanfaatan pembenah tanah untuk meningkatkan efisiensi pemupukan pada lahan sawah perlu dilakukan, sebab kegiatan intensifikasi dan estensifikasi pertanian dari program Bimas dan Inmas yang kurang mengindahkan kaidah pemupukan berimbang telah mengakibatkan semakin merosotnya kualitas lahan sawah, sehingga terjadi fenomena levelling off. Penelitian dilakukan di Lampung Tengah dengan tujuan 1) mengetahui tingkat efisiensi pemupukan di tingkat petani sebagai dampak dari penggunaan zeolit dan dolomit, : (2) mengetahui pengaruh pemberian zeolit dan dolomit terhadap perbaikan sifatsifat tanah dan produktivitas lahan. Metode yang digunakan dalam penelitian ini adalah metode survei, yakni pengumpulan data dilakukan melalui wawancara dengan menggunakan kuisioner terstruktur guna mengungkap karakteristik petani, identifikasi, dan prospek zeolit dan dolomit di masa depan. Hasil penelitian diperoleh bahwa jenis zeolit dan dolomit yang dikenal dan digunakan adalah: Zeolit Agro 2000, ZP.30 (Zeolit yang diperkaya hara P) dan dolomit. Penggunaan zeolit dan dolomit bermanfaat untuk meningkatkan produksi tanaman padi sekitar $10-30 \%$.
\end{abstract}

Kata kunci: Dolomit, Efisiensi Pemupukan, Zeolit

\begin{abstract}
One of alternative efforts to increase rice field soils quality which have degradated is through applying zeolit and dolomite combined with organic matter management along with spesific location balanced fertilizer system based on soil testing and nutrients need for the crop. Study of soil conditioner utilization for increasing fertilizer efficiency on paddy soils must be done, because agriculture intensive and extensive activity of Bimas and Inmas program did not considered the principles of balanced fertilizer which consequences the decreasing of paddy soils quality, finally lead to the occurrence a levelling off phenomenon. The research had been conducted in Centre Lampung district with the objectives, (1) to know fertilizer efficiency at the farmer level as the impact of zeolit and dolomite utilizing. (2) to know the efect of the soil physic and chemical and land productivity. The research method used was
\end{abstract}


survey methods, its mean that data collected pass through interview with the structure questioner to know farmer's characteristics, identification, and soils conditioner development prospect in the future. The results of this research found that, the kind of zeolit and dolomite which had been known and used were Zeolit Agro 2000, ZP.30 (enriched zeolit with P nutrient) and dolomite. Zeolit and dolomite utilization in both districts had benefit to increase rice crop production more or less $10-30 \%$.

Key words : Dolomite, Fertilization Efficiency, Zeolit

\section{PENDAHULUAN}

Upaya alternatif untuk meningkatkan kualitas lahan yang telah mengalami kemerosotan adalah mengaplikasikan pembenah tanah yang dikombinasi dengan pengelolaan bahan organik serta sistem pemupukan berimbang spesifik lokasi berdasarkan hasil uji tanah dan kebutuhan tanaman.

Pembenah tanah dapat digolongkan menjadi dua yaitu bahan pembenah tanah alami dan sintetis. Bahan pembenah tanah alami yang banyak digunakan oleh petani adalah kapur pertanian, fosfat alam, zeolit, bahan organik yang mempunyai $\mathrm{C} / \mathrm{N}$ rasio $7-$ 12 , blotong, sari kering limbah (SKL), emulsi aspal (bitumen), lateks atau skim lateks. Sedangkan bahan pembenah tanah sintetis yang sudah dipasarankan adalah VAMA, HPAN, SPA, PAAm/PAM, Poly-DADMAC, dan Hydrostock. Jenis-jenis pembenah tanah tersebut telah beredar di pasaran dan banyak digunakan petani, namun hingga saat ini masih sangat sedikit informasi yang menjelaskan sejauh mana pembenah tanah tersebut digunakan baik menyangkut jenis, dosisnya, dan pengaruhnya terhadap produksi pertanian.

Berdasarkan Peraturan Menteri

Pertanian Nomor: 02/Pert/Hk.060/2/2006 yang dimaksud dengan pembenah tanah adalah bahan-bahan sintetis atau alami, organik atau mineral yang berbentuk padat atau cair yang mampu memperbaiki sifat fisik, kimia, dan biologi. Di kalangan ahli tanah bahan pembenah tanah dikenal sebagai soil conditioner yang secara lebih spesifik diartikan sebagai bahan-bahan sintetis atau alami, organik atau mineral, berbentuk padat maupun cair yang mampu memperbaiki struktur tanah, dapat merubah kapasitas tanah menahan dan melalukan air, serta dapat memperbaiki kemampuan tanah dalam memegang hara, sehingga hara tidak mudah hilang, dan tanaman masih mampu memanfaatkannya.

Pemberian pupuk anorganik maksimum yang diupayakan petani sebaiknya dikombinasikan dengan pembenah tanah zeolit karena pada saat harga pupuk mahal, maka takaran pupuk anorganik dapat dikurangi sampai $50 \%$ dari takaran anjuran. Meskipun takaran pupuk dapat dikurangi, tetapi produksi tanaman yang dihasilkan masih menguntungkan, sebab: (1) kation $\mathrm{NH}^{4+}$ dari pupuk Urea yang dapat hilang melalui proses leaching dan volatilization dapat dicegah, kemudian kation $\mathrm{NH}^{4+}$ dari pupuk organik dan anorganik tersebut masuk dalam rongga-rongga dalam struktur Zeolit yang bermuatan negatif untuk ditahan sementara dan akan dilepaskan lagi untuk diserap tanaman, (2) sejumlah kation Al dan Fe tanah yang masuk dalam ronggarongga ditahan dalam struktur zeolit yang bermuatan negatif, sehingga anion $\mathrm{H}_{2} \mathrm{PO}^{4-}$ dari pupuk SP-36 sangat sedikit atau belum sempat diikat $\mathrm{Al} / \mathrm{Fe}$ akhirnya mudah diserap 
akar tanaman. Fenomena masuknya kation $\mathrm{NH}^{4+}$ ke dalam struktur mineral zeolit disebabkan zeolite clinoptilolite yang mempunyai nisbah Si/Al 4.5-5.0 dan KTK secara teori sekitar $225 \mathrm{cmol}(+) \quad \mathrm{kg}^{-1}$ mempunyai selectivity (kemampuan menyaring) kation dalam urutan dari besar sampai kecil.

Bertitik tolak dari permasalahan tersebut di atas, maka perlu dilakukan suatu kajian tentang sejauh mana pemanfaatan pembenah tanah oleh petani dan bagaimana pemahaman petani tentang manfaat pembenah tanah untuk memperbaiki kualitas tanah dan efisiensi pemupukan. Tujuan dari penelitian ini adalah: (1) mengetahui kendala dan peluang penggunaan pembenah tanah di tingkat petani, (2) mengetahui tingkat efisiensi pemupukan di tingkat petani sebagai dampak dari penggunaan pembenah tanah.

\section{BAHAN DAN METODE}

Penelitian dilaksanakan di Kecamatan Seputihraman, kabupaten Lampung Tengah. Responden ditetapkan berdasarkan 3 kategori yaitu petani pengguna dan petani pernah menggunakan/mantan pengguna dan petani tidak pernah menggunakan pembenah tanah. Jumlah petani responden 24 dan 27 orang. Metode penelitian yang digunakan adalah metode survei, yakni pengumpulan data primer dilakukan melalui wawancara dengan menggunakan kuisioner terstruktur guna mengungkap karakteristik petani, identifikasi, dan prospek zeolit dan dolomit di masa depan. Pada saat dilakukan survei, diambil contoh jenis pembenah tanah zeolit di toko dan distributor untuk dianalisis di laboratorium
Balai Penelitian Tanah Bogor. Parameter analisis yang ditetapkan adalah: kapasitas tukar kation (KTK), kandungan unsur P2O5, $\mathrm{K} 2 \mathrm{O}, \mathrm{Ca}, \mathrm{Mg}$, serta $\mathrm{pH}$ dan kadar air.

\section{HASIL DAN PEMBAHASAN}

Pengaruh zeolit dan dolomit terhadap tingkat efisiensi pemupukan

Berdasarkan hasil survei mengenai efisiensi pemupukan sebagai dampak penggunaan zeolit dan dolomit terhadap penggunaan pupuk Urea menunjukkan bahwa $86 \%$ responden petani pernah menggunakan menyatakan tetap dan $14 \%$ menyatakan berkurang dengan pengurangan takaran pupuk Urea sekitar 30-50\% (Gambar 1). Efisiensi pemupukan sebagai dampak penggunaan zeolit dan dolomit terhadap penggunaan pupuk SP-36 sebanyak $29 \%$ petani responden mantan pengguna menyatakan tetap dan $71 \%$ menyatakan berkurang, dengan pengurangan pupuk SP-36\% sekitar 25- 100\%. Efisiensi pemupukan sebagai dampak penggunaan zeolit dan dolomit terhadap penggunaan pupuk $\mathrm{KCl}$ sebanyak $86 \%$ petani responden mantan pengguna menyatakan tetap dan $14 \%$ menyatakan berkurang, dengan pengurangan pupuk $\mathrm{KCl}$ sekitar 0-100\%. Pengurangan pupuk SP-36 dan $\mathrm{KCl}$ sampai $100 \%$ adalah karena kelangkaan pupuk, harga pupuk mahal, dan zeolit dan dolomit dipersepsi sebagai pengganti pupuk.

Zeolit dan dolomit dapat menangkap sementara hara pupuk sehingga tidak hilang tercuci dan akan dilepaskan kembali untuk diserap akar tanaman. Zeolit dan dolomit mempunyai kerangka terbuka dengan jaringan pori-pori yang mempunyai permukaan bermuatan negatif dapat 
mencegah pencucian unsur hara $\mathrm{NH}_{4}{ }^{+}$-Urea dan kation $\mathrm{K}^{+}-\mathrm{KCl}$ keluar dari daerah perakaran. Zeolit dan dolomite berperan untuk menahan sementara unsur hara di daerah perakaran, sehingga pupuk Urea dan $\mathrm{KCl}$ yang diberikan lebih efisien. Jika takaran pupuk yang diberikan sesuai anjuran maka residu pupuk berakhir lebih lama dengan peningkatan hasil yang lebih tinggi. Sifat khas dari Zeolit sebagai mineral yang berstruktur tiga demensi, bermuatan negatif, dan memiliki pori-pori yang terisi ion-ion: $\mathrm{K}, \mathrm{Na}, \mathrm{Ca}, \mathrm{Mg}$ dan molekul $\mathrm{H}_{2} \mathrm{O}$, sehingga memungkinkan terjadinya pertukaran ion dan pelepasan air secara bolak-balik. Pupuk Urea dan $\mathrm{KCl}$ yang diberikan ke tanah yang sebelumnya sudah diberi zeolit, maka kation $\mathrm{NH}_{4}{ }^{+}$-Urea dan kation $\mathrm{K}^{+}-\mathrm{KCl}$ dapat terperangkap sementara dalam pori-pori zeolit yang sewaktu-waktu dilepaskan secara perlahanlahan untuk diserap tanaman.

Prakoso (2006) menyatakan bahwa kehilangan $\mathrm{N}$ pupuk dalam tanah dapat ditekan dengan pembuatan pupuk slow release fertilizer (SRF) yang dibuat dari campuran urea dan Zeolit dengan perbandingan urea:Zeolit (50:50) memiliki nilai efisiensi yang lebih tinggi dari pupuk SRF dengan perbandingan urea:Zeolit 70:30. Pupuk SRF dengan perbandingan urea:Zeolit 50:50 mampu menghemat 30\% penggunaan pupuk urea.

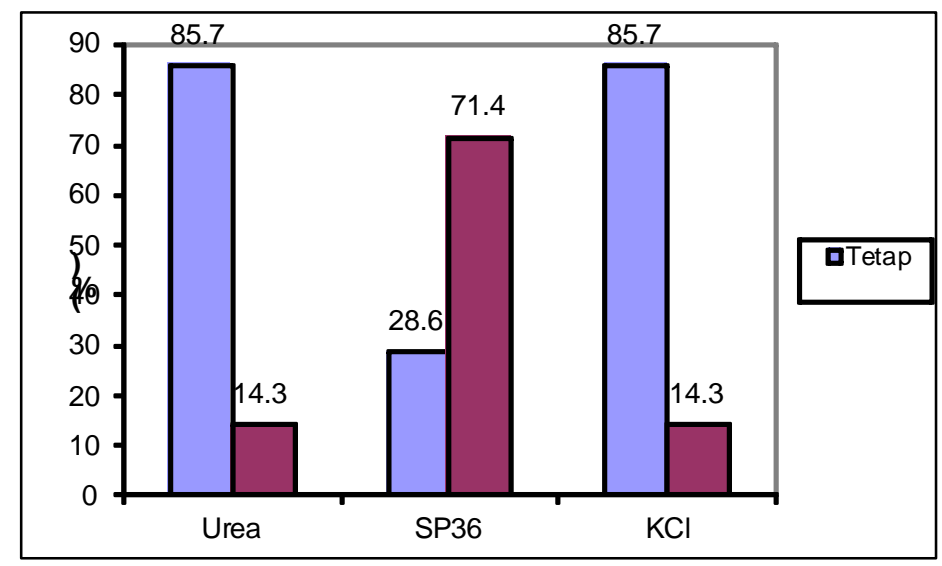

Gambar 1.Penggunaan zeolit dan dolomit terhadap efisiensi pemupukan

Pengaruh zeolit dan dolomite terhadap sifat - sifat tanah

Sifat-sifat tanah yang dipengaruhi zeolit dan dolomit antara lain adalah: (1) meningkatkan KTK tanah selama KTK zeolit diatas $100 \mathrm{cmol}_{(+)} \mathrm{kg}^{-1}$, jumlah Zeolit dan dolomit yang diberikan $\geq 5$ ton/ha untuk tanah mineral masam yang didominasi mineral liat 1:1, (2) meningkatkan kalium tanah, hal ini disebabkan kandungan $\mathrm{K}_{2} \mathrm{O}$ dalam Zeolit klinoptilolite sekitar 3\%, sehingga pemberian 5 ton Zeolit klinoptilolite $\mathrm{ha}^{-1}$ dapat mengkontribusi 150 $\mathrm{kg} \mathrm{K}_{2} \mathrm{O}$ jika semua kalium tersedia. Tidak semua $\mathrm{K}$ yang berada dalam Zeolit dapat digunakan dengan segera oleh tanaman, sehingga masih perlu diberi tambahan pupuk $\mathrm{K}$ dengan takaran yang lebih kecil, (3) meningkatkan ketersediaan $P$, dari hasil percobaan bahwa pemberian Zeolit pada tanah Podsolik meningkatkn $P$ dari 5.28 menjadi $20.1 \mathrm{mg} \mathrm{P}_{2} \mathrm{O}_{5} / \mathrm{kg}$ (Suwardi, 1997), 
dimana mekanisme peningkatan $\mathrm{P}$ diduga karena Ca dalam Zeolit mengikat $\mathrm{P}$ dalam tanah yang semula diikat oleh $\mathrm{Fe}$ dan $\mathrm{Al}$, dan karena $\mathrm{Ca}$ dalam Zeolit mudah dilepaskan dalam bentuk dapat dipertukarkan, maka $\mathrm{P}$ yang diikat $\mathrm{Ca}$ menjadi tersedia, (4) memperbaiki sifat-sifat fisik tanah seperti struktur tanah dan daya pegang tanah terhadap air. Perbaikan sifatsifat fisika dan kimia tanah ini akan meningkatkan keanekaragaman mikroflora dan fauna tanah yang penting dalam menjaga keseimbangan dinamis ekosistem tanah (Gupta, 1993).

Perbaikan struktur tanah dan daya pegang tanah terhadap air karena sifat fisik zeolit dan dolomit yang berongga, sehingga pemberian zeolit dan dolomit pada tanah bertekstur liat dapat memperbaiki struktur tanah, pori-pori udara tanah ditingkatkan, sedangkan Zeolit dan dolomit yang diberikan pada tanah berpasir dapat meningkatkan daya pegang tanah terhadap air. Pemberian zeolit dan dolomit sebagai pembenah tanah sebaiknya diberikan dalam bentuk campuran antara ukuran halus dan kasar agar pengaruhnya dapat bertahan untuk beberapa tahun, sebab jika semua zeolit yang diberikan $100 \%$ berukuran halus, akan memberikan pengaruh yang semakin baik akan tetapi daya tahannya lebih pendek.

Persen kejenuhan Al dapat digunakan sebagai parameter untuk menetapkan rekomendasi pengapuran. Tanaman padi sawah, jagung, dan kedelai tidak harus diberi kapur jika persen kejenuhan Al tanahnya masing-masing $\leq 60 \%, \leq 40 \%$, dan $\leq 20 \%$. Pembenah tanah kapur pertanian terdiri atas Kalsit $\left(\mathrm{CaCO}_{3}\right)$ dan Dolomit $\left.\left(\mathrm{CO}_{3} \cdot \mathrm{MgCO}\right)_{3}\right)$ berperan untuk memperbaiki pertumbuhan tanaman padi selama $\mathrm{pH}$ tanah di bawah 4.25, kandungan $\mathrm{Ca}$ dapat ditukar < $400 \mathrm{mg} \mathrm{Ca} \mathrm{kg}{ }^{-1}$ atau $<20 \mathrm{mg}$ $\mathrm{Ca} / 100 \mathrm{~g}$ atau $<2 \mathrm{cmol}_{(+)} \mathrm{kg}^{-1} \mathrm{Ca}$, kejenuhan Ca terhadap KTK < 25\% (Melsted, 1953). Meskipun persentase kejenuhan $\mathrm{Ca}$ pada tanah yang ideal sekitar $65 \%$, tetapi bukan berarti takaran kapur yang diberikan untuk tanaman padi harus mencapai kejenuhan $\mathrm{Ca}$ pada nilai $65 \%$, sebab dengan penggenangan tanah masam dapat meningkatkan $\mathrm{pH}$ tanah. Meskipun kebutuhan kapur (KK) dapat ditentukan melalui pendekatan formulasi: $\mathrm{KK}=$ faktor [(Al-dd+H-dd) - batas kritis \% kejenuhan Al $x$ (KTKefektif)] untuk lahan kering (Wade et al., 1986), tetapi tidak menutup kemungkinan formulasi tersebut digunakan untuk lahan basah.

Dolomit dalam bentuk $\left(\mathrm{CaCO}_{3} \cdot \mathrm{MgCO}_{3}\right)$ berperan untuk memperbaiki pertumbuhan tanaman padi selama $\mathrm{pH}$ di bawah 4.50, kandungan $\mathrm{Mg}$ dapat ditukar $<25 \mathrm{mg} \mathrm{Mg}$ $\mathrm{kg}^{-1}$ atau $<0.21 \mathrm{cmol}_{(+)} \mathrm{kg}^{-1}$, kejenuhan $\mathrm{Mg}<$ 5\%. Namun suatu jenis tanaman yang ditanam pada suatu tanah tertentu dengan kandungan $\mathrm{Mg}$ relatif rendah mungkin saja tidak respons terhadap pemupukan $\mathrm{Mg}$, hal ini disebabkan oleh karena ion $\mathrm{H}^{+}$yang berasal dari akar melalui proses pertukaran kation sangat efektif melepaskan bentuk Mg tidak dapat ditukar menjadi bentuk Mg dapat ditukar sehingga dengan mudah diserap akar tanaman (Christenson dan Doll, 1973).

Magnesium dapat ditukar sangat nyata berkorelasi dengan persentase kejenuhan Mg dan secara konsensus bahwa persentase kejenuhan Mg sekitar 5\% dari KTK tanah sudah cukup untuk hasil optimum dari berbagai jenis tanaman. Namun untuk tanaman-tanaman tertentu yang memerlukan konsentrasi kation-kation basa yang lebih tinggi dimana jeraminya dijadikan pakan untuk pencegahan penyakit 
hypomagnesaemia dari binatang memamah biak, maka persentase kejenuhan Mg sekitar $10 \%$ dari KTK adalah sangat dianjurkan untuk mempertahankan konsentrasi $\mathrm{Mg}$ dalam pakan ternak kering $\geq 0.2 \%$. Zeolit dan dolomit sebagai pembenah tanah yang diberikan ke dalam tanah dengan jumlah relatif banyak dapat memperbaiki sifat-sifat fisik, kimia, dan biologi tanah sehingga produksi pertanian dapat ditingkatkan (Pond dan Mumpton, 1984; Townsend, 1979; Suwardi dan Goto, 1996; Simanjutak, 2002; Suwardi, 2007).

\section{Pengaruh zeolit dan dolomit terhadap produktivitas lahan}

Aplikasi zeolit dan dolomit tidak sama dengan pembenah tanah lainnya (kapur pertanian dan gypsum), sebab zeolit tidak mengalami break down dan jumlahnya masih tetap dalam tanah untuk meretensi unsur hara. Aplikasi zeolit dan dolomit berikutnya akan lebih memperbaiki kemampuan tanah untuk menahan unsur hara dan memperbaiki hasil. Zeolit dan dolomit tidak asam dan penggunaannya dengan pupuk dapat menyangga $\mathrm{pH}$ tanah, sehingga dapat mengurangi takaran kapur. Pemberian zeolit dan dolomit tidak hanya digunakan sebagai carriers hara tanaman, tetapi juga sebagai perangkap logam berat $(\mathrm{Cu}, \mathrm{Cd}, \mathrm{Pb}, \mathrm{Zn})$ sehingga uptake kedalam rantai makanan atau food chain dicegah atau berkurang (Fuji, 1974). Namun kualitas zeolit baru terlihat jika pada proses produksinya dilakukan aktivasi sampai suhu $300^{\circ} \mathrm{C}$ (Astiana, 1993). Meskipun mutu zeolit alam dapat ditingkatkan setelah melalui proses aktivasi, tetapi tindakan aktivasi yang berlebihan baik dengan cara pemanasan, penambahan asam atau basa akan mengakibatkan kemampuan pertukarannya menurun, sebab terjadinya kerusakan struktur yang dapat diidentifikasi dari hilangnya intensitas puncak difraksinya pada hasil diffraktogram (Astiana, 1993). Hal ini ditunjukkan setelah aktivasi pemanasan $255^{\circ} \mathrm{C}$ zeolit Cikalong memiliki KTK $135.06 \mathrm{cmol}_{(+)} \mathrm{kg}^{-1}$, Bayah $121.78 \mathrm{cmol}_{(+)}$ $\mathrm{kg}^{-1}$, dan Cikembar $79.70 \mathrm{cmol}_{(+)} \mathrm{kg}^{-1}$, sedang setelah pengasaman $\mathrm{HCl} 0.25 \mathrm{~N}$, Zeolit Cikalong memiliki KTK $138.67 \mathrm{cmol}_{(+)} \mathrm{kg}^{-1}$, Bayah $115.77 \mathrm{cmol}_{(+)} \mathrm{kg}^{-1}$, dan Cikembar $90.34 \mathrm{cmol}_{(+)} \mathrm{kg}^{-1}$. Kemudian penambahan $\mathrm{NaOH} 0.5$ mengakibatkan zeolit Cikalong memiliki KTK $130.21 \mathrm{cmol}_{(+)} \mathrm{kg}^{-1}$, Bayah 119.01 $\mathrm{cmol}_{(+)} \mathrm{kg}^{-1}$, dan Cikembar $84.85 \mathrm{cmol}_{(+)} \mathrm{kg}^{-1}$.

Kristal zeolit paling efektif sebagai penukar kation. KTK Zeolit $>100 \mathrm{cmol}_{(+)} \mathrm{kg}^{-1}$ mampu menyerap air, mengadsorpsi $\mathrm{NH}_{4}^{+}$ dan $\mathrm{K}^{+}$, sehingga meningkatkan efisiensi penggunaan pupuk. Prihatini et al., (1987) melaporkan bahwa Zeolit sebagai pembenah tanah dengan takaran $\geq 1.000$ $\mathrm{ppm}$ atau $\geq 2$ ton/ha dapat meningkatkan KTK tanah mineral masam. Masalah utama yang ditemukan pada tanah mineral masam di Indonesia adalah rendahnya kesuburan tanah serta tingginya kandungan Al dapat ditukar (Al-dd), ternyata dapat diperbaiki dengan pemberian zeolit. Ada empat jenis zeolit pembenah tanah yang pernah digunakan petani responden, yakni: Zeolit Agro 2000, ZP.30 (Zeolit yang diperkaya unsur P), Zeolit biasa.

Zeolit dan dolomit baik dalam bentuk organik maupun mineral dapat diaplikasikan tidak hanya pada tanah kering, tetapi juga pada tanah sawah. Menurut Wade et al., (1986), pembenah tanah kapur pertanian tidak perlu diberikan apabila kejenuhan Al dalam tanah: $\leq 40 \%$ (jagung), dan $\leq 20 \%$ (kedelai), dan $\leq 60 \%$ (untuk padi sawah), sebab penggenangan sudah merupakan selfliming effect, kecuali jika Mg-dd $<0,5 \mathrm{cmol}_{(+)}$ $\mathrm{kg}^{-1}$ dan \% kejenuhan Mg terhadap KTK efektif 
$<5 \%$ maka zeolit dapat digunakan pada tanah-tanah dengan KTK sangat rendah $(<0,5$ $\mathrm{cmol}_{(+)} \mathrm{kg}^{-1}$ seperti pada tanah-tanah Regosol atau Inceptisols yang belum berkembang bertekstur pasir; Podsolik Merah Kuning atau Ultisols/Oxisols; dan Latosol Coklat atau Inceptisols/Ultisols (Simanjuntak, 2002). Sebaliknya Zeolit tidak dianjurkan pemberiannya pada jenis tanah yang mempunyai mineral liat alofan, sebab tidak dapat meningkatkan KTK tanah (Suwardi, 1997).

Sebanyak 23,8 \% petani responden pernah menggunakan Zeolit Agro 2000 dan ZP.30, sedangkan Zeolit biasa pernah digunakan $76,2 \%$ oleh petani responden. Jenis Zeolit Agro 2000 dan ZP.30 diaplikasi oleh $23,8 \%$ petani responden, sedangan Zeolit biasa $76,2 \%$ oleh pertani responden.

Hasil wawancara petani responden, aplikasi Zeolit Agro $2000+$ ZP.30 menaikkan hasil GKP, produksi gabah kering panen (GKP) dapat mencapai 5 ton/ha. Peningkatan produksi GKP tersebut juga dipengaruhi oleh pemberian Zeolit Agro 2000 + ZP.30, sehingga efisiensi serapan hara yang berasal dari pupuk kandang dan pupuk anorganik menjadi lebih tinggi. Sebaliknya, aplikasi Zeolit Agro 2000 + ZP.30 menurunkan hasil GKP, hal ini disebabkan pupuk SP-36 dan $\mathrm{KCl}$ juga dikurangi dan bahkan ada petani yang sama sekali tidak memberikan pupuk anorganik. Pupuk SP-36 tidak diberikan dengan alasan karena ZP.30 sudah diperkaya hara $\mathrm{P}$ dari pupuk $\mathrm{P}$ alam. Takaran pupuk SP-36 dan $\mathrm{KCl}$ juga dikurangi karena adanya anggapan bahwa zeolit adalah sebagai pupuk, dilain pihak petani sendiri tidak bisa membeli pupuk karena kelangkaan pupuk dan atau harganya yang mahal.

Pemberian 100 - $200 \mathrm{~kg}$ Zeolit Agro 2000/ha + $200-400 \mathrm{~kg}$ ZP.30/ha di Seputih
Raman tergolong rendah, disamping itu, KTK Zeolit Agro 2000 dan ZP. $30<80 \mathrm{cmol}_{(+)}$ $\mathrm{kg}^{-1}$. Takaran Zeolit yang diberikan tergantung pada tingkat degradasi lahan. Pada tingkat degradasi ringan dapat diberikan $\leq 5$ ton/ha, tingkat degradasi sedang antara 510 ton/ha dan untuk tingkat degradasi berat antara 10-20 ton/ha. Efektivitas zeolit lebih ditingkatkan melalui pemberiannya di zona perakaran, sehingga penggunaannya akan lebih efisien dan lebih praktis.

Meskipun 66\% petani responden pernah menggunakan mengatakan bahwa zeolit dan dolomit berpengaruh terhadap peningkatan produksi GPK, tetapi peningkatan produksi tanaman ini disebabkan teknis pelaksanaan inovasi teknologi yang dilakukan petani sudah benar. Sebaliknya 29\% petani responden pernah menggunakan mengatakan bahwa zeolit dan dolomit menurunkan produksi GKP, hal ini disebabkan teknis pelaksanaan inovasi teknologi yang dilakukan petani tidak benar, misal zeolit dan pupuk tidak dicampur rata. Peningkatan produksi GKP sebagai dampak penggunaan zeolit terutama disebabkan takaran pupuk anorganik yang diberikan sesuai dengan dosis anjuran, sebaliknya jika penurunan produksi GKP disebabkan takaran pupuk anorganik yang diberikan lebih rendah dari dosis anjuran.

Dari hasil wawancara dengan petani responden yang pernah menggunakan zeolit di Desa Seputihraman, Lampung Tengah dapat disimpulkan bahwa 5\% menyatakan bahwa produksi tanaman tetap, $29 \%$ produksi tanaman menurun, dan $66 \%$ produksi tanaman meningkat (Al-Jabri dan Juarsah, 2007).

Takaran zeolit yang dianjurkan $100 \mathrm{~kg}$ Zeolit Agro 2000 (50 kg pada lahan siap tanam dan $50 \mathrm{~kg}$ sebagai susulan) dan 200 kg ZP.30 (100 kg pada lahan siap tanam dan 
$100 \mathrm{~kg}$ sebagai susulan). Kemudian pupuk Urea diberikan sebanyak $200 \mathrm{~kg} / \mathrm{ha}$ dan pupuk $\mathrm{KCl}$ sebanyak $50 \mathrm{~kg} / \mathrm{ha}$ disesuaikan dengan kebiasaan dan pengalaman petani. Sedangkan pupuk SP-36 sama sekali tidak diberikan dengan alasan ZP.30 sudah diperkaya dengan hara $P$.

Peningkatan produksi GKP di Seputihraman meningkat berkisar 9.52 25\% (0.80 - 1.60 ton/ha) adalah disebabkan bukan hanya karena pengaruh Zeolit Agro 2000+ZP.30 saja, tetapi juga disebabkan oleh pemberian pupuk kandang, sehingga hara $\mathrm{NH}_{4}^{+}$dari pupuk Urea dan $\mathrm{K}^{+}$dari pupuk $\mathrm{KCl}$ terperangkap di dalam struktur zeolit dan dolomit yang secara lambat dilepaskan kembali untuk dimanfaatkan tanaman. Pada umumnya penggunaan pembenah tanah dolomit cenderung meningkatkan produksi GKP dan tongkol jagung, hal ini disebabkan tanah sawah didominasi mineral 1:1 (tipe kaolinit) yang dicirikan antara lain: $\mathrm{pH} \pm$ 4,50 (masam),
KTK $\pm 5 \mathrm{cmol}_{(+)} \mathrm{kg}^{-1}$ (rendah), Mg dapat ditukar 0,18 $\mathrm{cmol}_{(+)} \mathrm{kg}^{-1}$ (sangat rendah), kejenuhan $\mathrm{Mg}<5 \%$ (Al-Jabri dan Juarsah, 2007). Kandungan Mg dapat ditukar 0.18 $\mathrm{cmol}_{(+)} \mathrm{kg}^{-1}$ sangat rendah, dan jika tidak diberi Dolomit maka dipastikan tanaman kahat Mg.

Penurunan produksi GKP di Seputihraman berkisar $11-15 \%(0,60-$ 0,80 ton/ha) adalah disebabkan pupuk SP36 tidak diberikan karena ZP.30 diinformasikan sudah mengandung hara $\mathrm{P}$. Hasil analisis di laboratorium memperlihatkan bahwa kandungan hara $\mathrm{P}$ dalam ZP.30 hanya 0,13\% (artinya dalam $100 \mathrm{~kg}$ ZP.30 mengandung 0,13 kg P). Hasil analisis KTK, contoh Zeolit Agro 2000, ZP.30 dan Zeolit (produk PT Minatama) masing-masing adalah: 25, 64, dan $35 \mathrm{cmol}_{(+)} \mathrm{kg}^{-1}$ (Tabel 1), namun masih di bawah kriteria Permentan Nomor: 02/Pert/HK.060/2/2006 yakni $\geq 80$ $\mathrm{cmol}_{(+)} \mathrm{kg}^{-1}$.

Tabel 1 Analisis KTK, kandungan unsur P, K contoh Zeolit Agro 2000, ZP.30 dan Zeolit asal PT. Minatama Lampung.

\begin{tabular}{cccc}
\hline \multirow{2}{*}{ Jenis analisis } & \multicolumn{3}{c}{ Jenis Zeolit } \\
\cline { 2 - 4 } & Zeolit Agro 2000* & ZP.30* & Zeolit** \\
\hline KTK $\left(\mathrm{cmol}_{(+)} \mathrm{kg}^{-1}\right)$ & 25 & 64 & 35 \\
$\mathrm{pH}(1: 5)$ & 8,4 & 8,7 & 5,9 \\
$\mathrm{P}_{2} \mathrm{O}_{5}(\%)$ & 0,01 & 0,13 & 0,11 \\
$\mathrm{~K}_{2} \mathrm{O}(\%)$ & 0,01 & 0,01 & 0,03 \\
$\mathrm{Ca} \mathrm{( \% )}$ & 21 & 8 & 1,16 \\
$\mathrm{Mg}(\%)$ & 0,21 & 0,24 & 0,27 \\
\hline
\end{tabular}

Keterangan: Sumber : Laboratorium Balai Penelitian Tanah Bogor

* = Zeolit Agro 2000 dan ZP.30 diproduksi PT. Jaya Sakti. JI. Raya Solo-Seragen KM. 12 1⁄2 No. 88, Kebak Kramat, Karang Anyar;

** = Zeolit yang diproduksi PT. Minatama di Jl. Terusan Slamet Riyadi, No. 3 Teluk Betung, Bandar Lampung

Kandungan KTK contoh ZP.30 adalah 64 $\mathrm{cmol}_{(+)} \mathrm{kg}^{-1}$ yang dinilai sudah cukup tinggi, namun masih berada di bawah kriteria Permentan No. 02/Pert/HK.060/2/2006. $\geq$
$80 \mathrm{cmol}_{(+)} \mathrm{kg}^{-1}$. Perbedaan nilai KTK Zeolit yang ditetapkan berdasarkan prosedur penetapan KTK sebagaimana yang diberlakukan untuk contoh tanah selalu 
lebih rendah dibandingkan dengan prosedur penetapan KTK Zeolit yang ditetapkan dengan prosedur SNI, hal ini disebabkan oleh ukuran besar butir zeolit dan nisbah zeolit terhadap larutan amonium asetat. Semakin halus ukuran besar butir dan semakin lebar nisbah zeolit terhadap larutan amonium asetat maka semakin tinggi nilai KTK Zeolit.

\section{SIMPULAN}

1. Efisiensi pemupukan sebagai dampak penggunaan zeolit dan dolomit terhadap penggunaan pupuk $\mathrm{KCl}$ sebanyak $86 \%$ petani responden mantan pengguna menyatakan tetap dan $14 \%$ menyatakan berkurang, dengan pengurangan pupuk $\mathrm{KCl}$ sekitar 0-100\%.

2. Penggunaan zeolit dan dolomit dapat memperbaikan sifat fisik dan kimia tanah, meningkatkan keanekaragaman mikroflora dan fauna tanah yang penting dalam menjaga keseimbangan dinamis ekosistem tanah. Karena sifat fisik zeolit dan dolomit yang berongga, pemberian Zeolit dan dolomite pada tanah yang bertekstur liat dapat memperbaiki struktur tanah, pori-pori udara tanah ditingkatkan dan daya pegang tanah terhadap air.

3. Aplikasi Zeolit Agro $2000+$ ZP.30 menaikkan hasil GKP, produksi gabah kering panen (GKP) dapat mencapai 5 ton $\mathrm{ha}^{-1}$. Peningkatan produksi GKP tersebut juga dipengaruhi oleh pemberian Zeolit Agro 2000 + ZP.30, sehingga efisiensi serapan hara yang berasal dari pupuk kandang dan pupuk anorganik menjadi lebih tinggi.

4. Kendala internal penggunaan zeolit menurut persepsi petani responden adalah kurangnya informasi/ penyuluhan, aplikasinya sulit, butuh tambahan tenaga kerja, sedangkan kendala eksternal adalah: harga masih mahal, tidak selalu tersedia di toko, ketersediaannya yang terbatas.

\section{DAFTAR PUSTAKA}

Al-Jabri, M. dan I. Juarsa. 2007. Produktivitas tanaman padi sawah pada tanah mineral masam di Lampung Timur. Prosiding Seminar dan Kongres Nasional HITI, Buku 1, halaman 301-309, 5-7 Desember 2007, UPN "VETERAN" YOGYAKARTA.

Astiana, S. 1993. Perilaku mineral Zeolit dan pengaruhnya terhadap perkembangan Tanah. Program Pascasarjana. IPB.

Christenson, D.R., and E. C. Doll. 1973. Release of magnesium from soil clay and silt fractions during cropping. Soil Sci. 116:59-63.

Fuji, Shigeharu. 1974. Heavy metal adsorption by pulverized Zeolites: Japan. Kokai 74,079,849, Aug. 1, 1974, 2 pp.

Gupta, V. V. S. R. 1993. The impacts of soil fauna and crop management practices on the dynamics of soil microfauna and mesofauna. $P$ 107-124 In C. E. Pankhurst, B. M. Doube, V. V. S. R.. Gupta, and P.R. Grace (Eds.). Soil Biota: Management in Sustainable Farming System. CSIRO. Press, Melbourne, Australia.

Mumpton, F. A., and P. H. Fishman. 1977. The application of natural Zeolites in animal science and aquaculture. J. Anim. Sci. 45:1188-1203.

Pond, W. G., and F. A. Mumpton (Ed). 1984. Zeo-agriculture: Use natural Zeolites in agriculture and aquaculture. International Committee on Natural Zeolite, Westview Press, Boulder, CO. 
Prakoso, T. G. 2006. Studi slow release (SRF): Uji efisiensi formula pupuk tersedia lambat campuran urea dengan Zeolit. Departemen IImu Tanah dan Sumberdaya Lahan. Fakultas Pertanian. IPB.

Prihatini, T, S. Moersidi, dan A. Hamid. 1987. Pengaruh Zeolit terhadap sifat tanah dan hasil tanaman. Pemberitaan Penelitian Tanah dan Pupuk. No. 7: 5-8. Pusat Penelitian Tanah, Badan Litbang Pertanian, Departemen Pertanian.

Simanjuntak, M. 2002. Penggunaan Zeolit dalam bidang pertanian. Program Studi Ilmu Tanah. Jurusan Tanah. Fakultas Pertanian. IPB.

Suwardi and Goto, I. 1996. Utilization of Indonesian Natural Zeolite in Agriculture. Proceedings of the International Seminar on Development of Agribusiness and Its Impact on Agricultural Production in South East Asia (DABIA), November 1116, 1996 at Tokyo.

Suwardi. 1997. Studies on agricultural utilization of natural Zeolites in Indonesia. Ph. D. Dissertation. Tokyo University of Agriculture.

Suwardi. 2007. Pemanfaatan Zeolit untuk Perbaikan Sifat-sifat Tanah dan Peningkatan Produksi Pertanian. Disampaikan pada Semiloka Pembenah Tanah Menghemat Pupuk Mendukung Peningkatan Produksi Beras, di Departemen Pertanian, Jakarta 5 April 2007. (Tidak dipublikasikan).

Townsend, R. P. 1979. The properties and application of Zeolites. The Proceeding of A Conference Organized Jointly by the Inorganic Cehemicals Group of the Chemical Society and the Chemical Industry. The City University, London, April 18th - 20th.

Tsutsuki, K. 1983. Anaerobic decomposition of organic matter in submerged soils. A terminal report submitted to the
International Rice Research Institute, Los Banos, Philippines.

Wade, M. K., M. Al-Jabri, and M. Sudjadi. 1986. The effect of liming on soybean yield and soil acidity parameters of three red yellow podzolic soils of West Sumatera. Pemberitaan Penelitian Tanah dan Pupuk. 6:1-8. Pusat Penelitian Tanah, Badan Litbang Pertanian, Departemen Pertanian. 